\title{
QK5 572
}

.W4

W4

West, William

On some freshwater algae from the West Indies. 


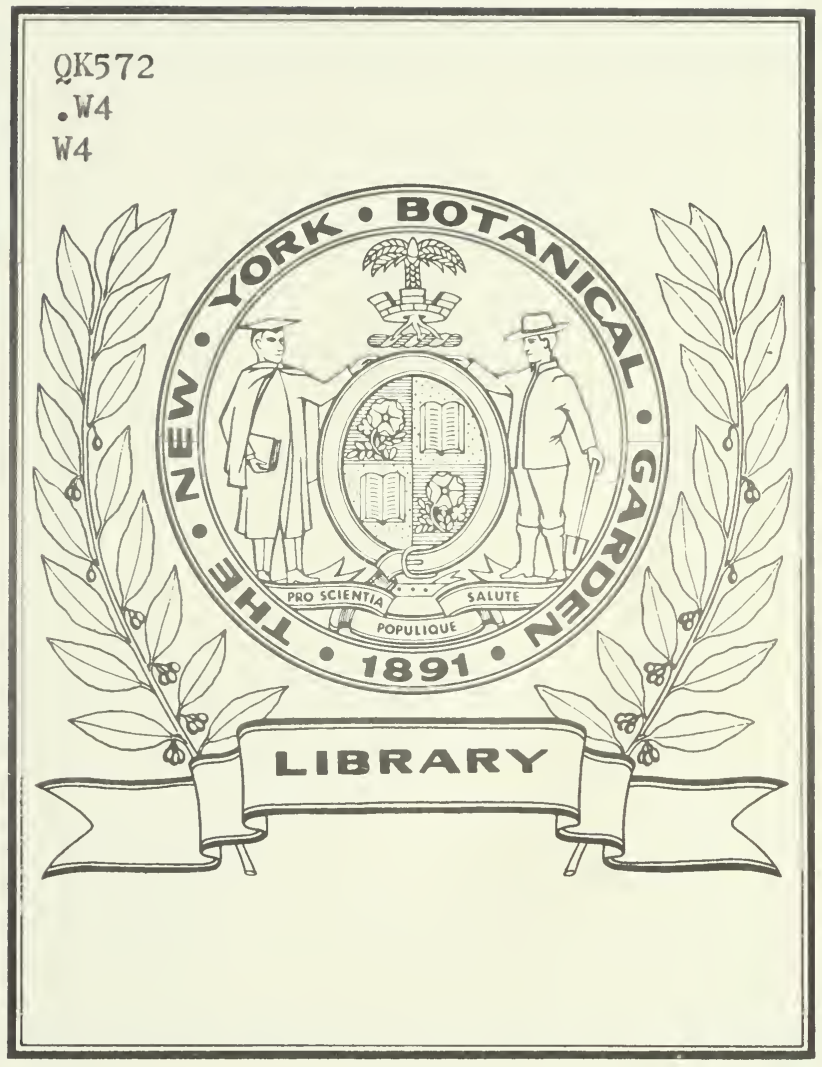






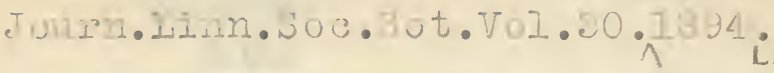

Un sume rreshrater Alecte from the west Nisi ilikt Inaies. 3y m. Mest, F.2.S. assisteu by . S. West. (Read Ist Feí. 1834)

\section{Ilates LIII. - $\mathrm{IVI}$ :}

Whrough the kindness of lin. Georee liurray, uI the 3ritish lusour, I have of en enabled to examine sone reshwater 1 lede which were collected by Ir. W. R. Wlilott on the islands oI Dominica and t. Vircent from the former in Jovember cind )ecember 1892, and from the latter in tar of the sane year. The material was preserved in veak Spirit, and has proved to de $v \in I y$ interesting. Lhe alsae vere in nunverea bottles; these nunbers are usea thromichont the paper, as both material ano slides, with correspondin numers, can be consultea in the lisenm.

rhe strictlr aquatic species vere mostly frun warn or hot streams. I'hree of the zutherings viere itrom moSSY treEs; these litter must have been $v \in$ ry mist have been very moist, as several species of Jesmidiese occurred anonsi the various Cyanophreese wiul formed the ereater part of this matcrial. Sone of the species were very abuniart, e. E. Symploca cuspidata, n. Sp.; there vere others intemingled with these, either in small patches or solitare, and very sparing

Sunnary G Genera.Species. \& Furms.

Cunfe rvacede

\section{C \\ Z}

\section{D}

\section{$\mathrm{V}$} veinene ... Irotococcaceae IIostocaceae. Scytonemaceae. Sirusibiuniaceae Oscillariaceae Chroococcaceae Dictonaceae 

"Crass. fil." (as used in this paper) = the diameter of the sheath containing the trichomes.

"Crass. trich." = the diameter of the cells without the sheath.

\section{Class CoNFER V I DE}

\section{Ord. Confertacex.}

1. Conferta bombicina, Ag., forma miror, Wille. (Om Hvileceller hos Conferva, p. 21, t. 1. figs. 36-40, t. 2. figs. 55, 56.)

Crass. fil. $6 \cdot 5-7 \cdot 5 \mu$.

Hab. In cold, warm, and hot streams, crater of Grande Soufrière, Domivica. Nos. $850,883,884$, and 908.

2. Rimzoclonid ar Berggrexiayum, Hauck in Nordst. Freshu. Alg. of New Zeal. \& Australia, p. 17. Var. Dominicense, nov. var. (Pl. XIV. figs. 17-24).

Var. filamentis dense intricatis, tenuior, articulis diametro 2-3plo longioribus; membrana cellularum $1 \mu$ crassitudine.

Crass. cell. reget. 9-10 $\mu$.

Hab. In hot stream in crater of Grande Soufric̀re, Dominica. No. 880 .

In the more densely intricate portions almost every cell emitted a short lateral branch, usually consisting of one cell.

\section{Ord. Chroolepide.e.}

3. Trentepohlia odorata, Wittr. (Scand. Vïxter.t.4.p. 16.) [Chroolepus odoratum, Ag. Syst. Alg. p. 35.]

Crass. cell. veget. $12-20 \mu$; crass. zoogonidang. $33-37 \cdot 5 \mu$.

T. zoogonidangiis lateralibus, interdum terminalibus, subglobosis, sessilibus (hinc inde pedicellatis).

Hab. On bark, Bow-wood Hills (1580 ft.), St. Vincent. (S-12-91.) No. 23.-On trees, Government House, St. Vincent, $900 \mathrm{ft} . \quad(10-12-91$.$) No. 27$.

4. T. Tillosi, De Toni. (Syll.'Alg. i. p. 239.) [Chroolepus villosa, Kuetz. Phyc. gener. p. 234; Species Algarum, p. 428.]

Crass. cell. veget. 18-23 $\mu$.

Hab. On rocks, Soufrière, Dominica. (2-7-92.) No. 20. LINN. JOURN.-BOTANY, TOL. XXX. 


\section{Class C O N J G A T}

\section{Ord. ZrgnemACEE.}

5. Ziggnema (Zygogonidm) Pachidermum, nov. sp. (Pl. XIII. figs. 1-16.)

$Z$. cæspitibus intricatis; filis flexuosis (et interdum genuflexuosis) dense intricatis, hinc inde ramulis brevibus irregularibusque cellularum 2-6; cellulis vegetativis diametro $2-2 \frac{1}{2} p l o$ (sæpe 3plo) longioribus (rarius æqualibus); membrana cellularum crassa vel crassissima; zygosporis in tubo conjugationis brevi inter cellulas sitis, subglobosis, subellipsoideis, plerumque irregularibus (sæpe constrictis); membrana zygosporarum crassissima, irregulariter lamellosa; azygosporis globosis subglobosisque, zygosporis similibus sed membrana tenuiore.

Crass. cell. veget. $16-23 \mu$ (usque ad $26 \mu$ et plerumque $20 \mu$ ); crass. membr. cellulaıum $1.5-5.5 \mu$; long. zygosp. 25.5-33 $\mu$ (usque ad $40 \mu$ ); lat. zygosp. 19-26 (usque ad $30 \mu$ ); crass. membr. zygosp. $2.5-6.5 \mu$; diam. azygosp. 23-26 $\mu$; crass. membr. azygosp. $1 \cdot 9-3 \cdot \mathrm{S} \mu$.

Hab. In mud, warm stream, crater of Grande Soufrière, Dominica. No. SS3; also in no. 908, and sparingly from no. 8S2.-This also occurred, without zygospores, on old wall, Roseau, Dominica. (1-S-92.) No.473.

This species has a thick membrane which at first sight reminds one of a Rhizoclonium or a large species of Conferva, the somewhat irregular filaments with short branches resembling the former especially. The many examples of conjugation examined were all scalariform, the zygospores completely filling the short conjugating-tube, their variability being remarkable, Spores were seen (figs. 9-10) which were undoubtedly azygospores, and these were regular in shape. One example was noticed where the zygospore was double. The material was preserved in weak spirit; but the two chromatophores were in most examples distinct aud in their normal position.

Var. confervoides, nov. var. (Pl. XIV. figs. 1-6.)

Var. cellulis tenuior, diametro plerumque $1-1 \frac{1}{2}$ plo (rarius $2 \frac{1}{2} p l$ (1) longioribus.

Crass. cell. veget. $10-13 \mu$.

IIab. In mud, warm stream, crater of Grande Soufrière, Dominica. No. S53. Intermingled with the typical form, but not so abundant. 
This variety has the cells of the filaments often somewhat doliform, and closely resembles a Conferva; it does not, however, break up in the peculiar manner of any species of Conferva (vide fig. 6). The binate chromatophores also put it out of this genus. Fig. 4 probably represents an attempt at conjugation.

Two cells are figured (fig. 5) which show an attempt at longitudinal division.

\section{Ord. Desmidiace..}

6. Mesotenium micrococcum, Firchn. (Alg. Schles. p. 131.) [Palmoglea micrococca, Kuetz. Tabule phycolog. i. p. 20, t. 25. f. 5.]

Long. cell. $15 \cdot 5-17 \cdot 3 \mu$; lat. cell. $7 \cdot 5-9 \mu$.

$H a b$. On trees among mosses, summit of Trois Pitons ( $4500 \mathrm{ft}$.), Dominica. Nos. 903 and 904.-On Bow-wood Hills (15S0 ft.), St. Vincent. (8-12-91.) No. 23.

7. M. culamyosporca, De Bary. (Conj. p. 75; Cooke, Brit. Desm. p. 4i, pl. 1S. f. 14; West, Freshw. Alg. of W. Ireland in Journ. Linn. Soc. vol. xxix. p. 131, pl. xxiv. f. S.)

Long. cell. 19-23 $\mu$; lat. cell. $12 \cdot 5-14 \cdot 5 \mu$.

Hab. On trees among mosses, summit of Trois Pitons (4500 ft.), Dominica. Nos. 903 and 901.

S. Tetaremorus leris, Ralfs. (Brit.Desm.p. 147, t.24. f. 2.) Long. 57.5-65 $\mu$; lat. 19-20 $\mu$; lat. isthm. 17.5-18.5 $\mu$.

Hab. In mud, warm strean, crater of Grande Soufrière, Dominica. No. 883 .

9. Cosmarium Pseudopiramidatum, Lund. (Desm. Suec. p. 41, t. 2. f. 18.)

Long. $46-48 \mu$; lat. $24-25 \mu$; lat. isthm. $9 \cdot 5-12 \cdot 5 \mu$.

Hab. On damp wall of dam, Sharp's River, St. Tincent. No. 477 .

*stexonotum, Nordst. in Wittr. et Nordst. Desm. et Edog. in Ital. et Tyrol, p. 32, t. xii.f. 8. Forma Mixor, Racib. (Desmidya w podrózy na oklo ziemi, p. 4, t. i. f. 32). (Pl. XIV. fig. 25.)

Long. $36-36.5 \mu$; lat. $23-24 \mu$; lat. isthm. $6.5 \mu$; crass. $13.5 \mu$.

Hab. With the typical form, but much more abundant.

10. C. obliqudu, Nordst. (Bidrag till känned. om Sydligare 
Norges Desm. p. 23, t. 1. f. 8). Forma MiNor, Nordst. (7. c.). (PI. XIII. fig. 17.)

Long. $14.5 \mu$; lat. $11.5 \mu$; lat. isthm. $6.5 \mu$; crass. $9.5 \mu$.

Hab. Amongst Symploca cuspidata, n. sp., on trees, summit of Trois Pitons (4500 ft.), Dominica. No. 904.

This interesting species seems to have a varied kind of habitat, occurring in small upland tarns and pools, on dripping subalpine rocks, and in the present instance on damp mossy trees.

11. Cosmarium Cucurbita, Bréb. (Ralfs, Brit.Desm.p. 108, t. 17.f. 7.)

Long. $40 \mu$; lat. $21 \mu$; lat. isthm. $19 \mu$.

ILab. On trees among mosses, summit of Trois Pitons (4500 ft.), Dominica. No. 903.

Class C๘ х В В Е

Ord. Volvocinex.

12. Eudorina stagnale, Wolle. (Freshw. Alg. of U.S.p. 160, pl. clii. figs. 11-21.)

Var. cellulis parvis et distantibus. (Pl. XVI. fig. 10.)

Diam. cell. $4 \cdot 8-5 \cdot 6 \mu$; diam. cœnob. $63 \mu$.

Hab. Amongst mosses on trees, with Hapalosiphon intricatus, 11. sp., and Symploca cuspidata, n. sp., summit of Trois Pitous (1500 ft.), Dominica. No. 903.

Class P R OTOCOCCOIDEE.

\section{Ord. Protococcacee (incl. Palmellacea).}

13. Urococcus insignis, Kuetz. [Chlorococeus macrococeus, Rabh., et var. aureus, Rabh. Fl. Europ. Alg. ii. p. 33.]

Diam. cell. 23-31 $\mu$; c. teg. $42 \mu$.

Hab. On mossy trees, summit of Trois Pitons (4500 ft.), Dominica. Nos. 903 and 904.

14. Cerasterias staurastroides, nov. sp. (Pl. XIV.fig. 16.)

C. quadriradiata e corpore distincto, radiis elongatis sensim attenuatis et minute granulatis, apice obtusis.

Diam. c. proc. 30-35 $\mu$; diam. corpor. circ. 9-9.5 $\mu$.

Hab. With Scytonema javanicum, Bornet, amongst mosses, on lime-trees, Shanford Estate, Dominica. No. 901.

The rough arms of this species remind one very forcibly of a small Staurastrum, and sufticiently characterize it. 


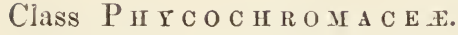

Subclass Nostochine..

\section{Ord. Nostocace.}

15. Nostoc humfusur, Carm. ex Harvey in Hooker's Brit. Flora, ii. p. 399. (Kuetz. Species Algar. p. 301; Rabh. Fl. Europ. Alg. ii. p. 1S3.)

Diam. cell. $2-3 \mu$; diam. heterocyst. $3 \cdot 5 \mu$.

Hab. On lime-trees, Shanford Estate, Dominica. No. 901.On trees, summit of Trois Pitons ( $4500 \mathrm{ft}$.), Dominica. No. 903.

16. N. sphericum, Vaucher. (Cooke, Brit. Freshw. Alg. p. 231, t. 91. ff. 8-11; Bornet et Flahault, Révis. des Nostoch. Hétérocyst. p. 208.)

Diam. cell. $3.8 \mu$; diam. heterocyst. $5-5 \cdot 7 \mu$; diam. thall. usque ad $10 \mathrm{~mm}$.

$H a \bar{b}$. On damp wall of dam in Sharp's River, St. Vincent. No. 477 .

\section{Ord. Scrtoremace.e.}

17. Мicrochete texuissima, nov. sp. (Pl. XIV. figs. 7-11.) II. inter algas varias alias reperta; filis tenuissimis, subintricatis, contortis; vaginis hyalinis, achrois, amplis; articulis elongatis, diametro 5-9plo longioribus, articulis junioribus brevioribus (circiter diametro duplo longioribus) et crassioribus; heterocystis intercalaribus, subquadratis vel oblongis.

Crass. fil. $4 \cdot 4-5 \cdot 1 \mu$; crass. trich. $1-1 \cdot 9 \mu$; crass. heterocyst. 2-2.4 $\mu$; long. heterocyst. $3 \cdot 5-6 \cdot 5 \mu$.

Hab. Amongst Symploca cuspidata, n. sp., on trees, summit of Trois Pitons (4500 ft.), Dominica. No. 904.

18. Scrtonema Javanteum, Bornet (in Bornet et Thuret, Notes Algologiques, p. 148 ; Bornet et Flah. Révis. des Nostocl. Hétérocyst. p. 95). [Symphyosiphon javanicus, Kuetz. Species Algarum, p. 323 ; Tabula phycolog. ii. p. 13, t. 43. f. i.] (Pl. XIV. figs. 12-15.)

Crass. fil. 13-16 $\mu$; crass. trich. 8.5-11 $\mu$.

Hab. On lime-trees, Shanford Estate, Dominica. No. 901.Anguilla, W. Indies. (23-3-92.) No.70.-On the walls, Roseau, Dominica. (9-7-92.) No. 236.

The above agrees well with this species, the most notable dif- 
ference being in the branches not being aggregate. The heterocysts vary from subquadrate to subrotund, and are rather numerous.

19. Scytonema amplum, nov. sp. (Pl. XVI. figs. 14-16.)

S. strato parvo, pannoso, $3-5 \mathrm{~mm}$. lato, fusco ; filis dense intricatis; pseudoramis sparsis plerumque geminatis sed interdum singulis, filo primario tenuioribus; vaginis amplissimis strat is parallelis formatis, in parte exteriore gelatinoso-achrois vel subluteolis, in parte interiore abrupte luteo-fuscis; trichomatibus angustis, luteo-viridibus, ad apicem pseudo-ramulorum crassioribus et articulis brevioribus; articulis diametro $3 \frac{1}{2}-6$ plo (plerumque 4plo) longioribus; heterocystis oblongis, diametro $3-3 \frac{1}{2}$ plo (rarius 2plo) longioribus.

Crass. fil. prim. 19-24 $\mu$; crass. ramul. $13.5-16 \mu$; crass. trich. $3 \cdot 5-4 \mu$.

Hab. On trees, summit of Trois Pitons ( $1500 \mathrm{ft}$. ), Dominica. Nos. 903 and 901.-Growing about and upon the surface of Symploca cuspidata, n. sp.

The nearest species to this with regard to the comparative length and breadth of the cells is $S$. ambiguum, Kuetz., from which it differs in its much larger size, stouter habit, comparatively broader sheath, and in the more unfrequent branches. The branches are usually geminate though not unfrequently single, and they are always thinner than the primary filament. The trichomes at the apices of the branches become almost twice as thick, the cells becoming very much shorter. S. myochrous, Ag., is somewhat similar though larger, and has not such a comparatively broad sheath, and the latter is ocreate.

20. S. ambigcur, Liuetz. (Species Algarum, p. S94; Tabula phycolog. ii. p. 7, t. 26. f. ii.) (Pl. XV. figs. 11-15.)

Crass. fil. $9 \cdot \bar{\jmath}-11 \cdot \bar{\jmath} \mu$; crass. trich. $2-2 \cdot \bar{\jmath} \mu$.

Hab. On trees, summit of Trois Pitons (4500 ft.), Dominica. No. 903.-On the ground, mostly in old Diablotia holes, Morne Anglais (2300 ft.) (15-7-92.) No. 493. Amongst Symploca.

The figure given by Kuetzing $(l . c$.$) is very indistinct; but the$ specimens agreed well with the description given by Bornet and Flahault (Révis. des Nostoc. Hétérocyst. p. 100), excepting that the filaments were a little thicker $(9 \cdot 5-11 \cdot 5 \mu$ against $6-9 \mu)$. The trichomes were, however, the same. One of its chiet characters is its long and varrow cells, which get shorter and thicker (up to $3 \cdot 8 \mu$ ) towards the apices of the young 
branches; the sheath also becomes hyaline. The cells often appeared like the section of a biconcave lens, owing to the contraction produced by the dilute spirit in which the material was preserved.

21. Scrtonema figuratum, Agardh. (Syst. Algar. p. 38.) [Scytonema calotrichoides, Kuetz. Species Algarum, p. 307; T'abula phycolog. ii. p. 6, t. 22. fig. ii. ; Rabh. Fl. Europ. Alg. ii. p. 253.]

Crass. fil. $15 \cdot 5-23 \mu$; crass. trich. $18-13 \cdot 5 \mu$.

Hab. On damp wall of dam, Sharp's River, St. Vincent. No. 477.-On trees, summit of Trois Pitons (4500 feet), Dominica. Nos. 903 and 904 .

\section{Scitonema, sp.}

Crass. fil. $28-36 \mu$; crass. trich. $5-5 \cdot 5 \mu$.

Hab. Amongst S. javanicum, Bornet, on lime-trees, Shanford Estate, Dominica. No. 901.

Only a smali quantity of this was seen, which was insufficient for accurate determination. The characters were those of S. densum, Bornet, and it probably is a small variety of this species.

23. Tolprothrix texuis, Kuetz. (Phycolog. gener. p. 22s; Tabula phycolog. ii. p. 9, t. 31. f. ii.) [T. pygmæa, Kuetz. T. flaccida, De Bary.]

Crass. fil. $7-7 \cdot 7 \mu$; crass. trich. $5 \cdot 7 \mu$; heterocyst. $7 \cdot 7 \times 5 \cdot 7 \mu$. Hab. On damp wall of dam, Sharp's River, St. Vincent. No. 477 .

\section{Ord. Sirosiphoniace.e.}

24. Hapalosiphov intricatus, nov. sp. (Pl. XV. figs. 16-29.)

$H$. cæspitibus parvis, æruginosis ; filis densissime intricatis et variabilibus, adultis vaginis arctis distinctis (interdum paullo indistinctis) e cellulis singulis formatis, sparsim ramosis; ramis singulis unilateralibus flexuosis, filo primario subsimilibus, vaginatis vel evaginatis; cellulis variabilibus, diametro $1 \frac{1}{2}-3$ plo longioribus, sæpe æqualibus et subrotundis, interdum elongatis; heterocystis intercalaribus, subquadratis vel oblongis (diametro 1-3plo longioribus).

Crass. fil. 4-7 $\mu$; crass. heterocyst. 3.8-5.5 $\mu$.

Hab. In little intricate tufts among the leares of Leucobryum, on trees, summit of Trois Pitons (4500 ft.), Dominica. No.903. 
The nearest species to this hitherto described is H. laminosus, Hansg. ["Ueber den Polymorph. der Alg.," Botan. Centralb. 1885, p. 48 ( $c f r$. Bornet et Flah. Révis. des Nostoc. Hétérocyst. p. 55)], from which it differs, however, in not being calcified in any way, in being a little larger, in having its single and unfrequent branches of a similar thickness to the primary filaments without any attenuation, and in its peculiar habitat. The heterocysts are of the same breadth as that of the cells (or narrower), whilst those of $H$. laminosus are often broader. Like the latter, the threads are very variable, being sometimes similar to an Anabcena, sometimes like a Lyngbya, while at other times the cells are quite irregular and somewhat inflated. Some examples showed the rounded granulose bodies noted by Hansgirg in $H$. laminosus (Bemerkungen zur Systematik einiger Süsswasseralgen, p. 18). These bodies when fully formed appear to be thick-walled (figs. 23-28) and have a diameter of 6-13 $\mu$.

The cell of the primary filament immediately under a branch always projects more or less into the sheath of the branch.

25. Hapatostpion flexcosus, Borzi. (Alghe d'acq. dolc. d. Papua, in Nuovo Notarisia, Apr. 1S92, p. 43.)

Crass. fil. $7 \cdot 5-8 \cdot 5 \mu$; crass. cell. $5 \cdot 5-6 \mu$; long. cell. $4-4 \cdot 5 \mu$.

Hab. In stream, Grande Suufrière, Dominica. No. SS4.

26. II. АRBoreus, nor. sp. (Pl. XV. figs. 1-3.)

$H$. inter alias algas repertus; filis primariis flexuosis, passim ramosis uno latere e cellulis singulis formatis, cellulis diametro 1-1 $\frac{1}{2}$ plo (rarius 2plo) longioribus, vagina arcta, tenui, et achroa ; filis secundariis brevibus, crassitudine filis primariis similibus sed subtenuioribus, cellulis diametro subrqualibus; heterocystis quadrato-oblongis, intercalaribus.

Crass. fil. $7-10 \mu$; crass. cell. $7-9.5 \mu$; heterocyst. $6-9 \mu$ $\times 9-11 \mu$.

Hab. On trees, summit of Trois Pitons (4500 ft.), Dominica. No. 903.

The nearest species to this is H. Alexuosus, Borzi (1.c.), from which it differs in not possessing flexuose intricate branches on every side; it is also a rather larger species, with cells often a little longer than broad and never depressed.

27. Stigonema honmomes, Bornet et Flah. (Révis. des Nostoc. Hétérocyst. p. 69.) [Scytonema hormoides, Kuetz. Sirosiphon brevis, Ḱuetz. Botan. Zeit. 1817, p. 196 ; Tabula phycolog. ii. 
p. 10, t. 34. f. ii. Sirosiphon hormoides, Kuetz. Species Algar. p. 316 ; Tabula phycolog. ii. p. 10, t. 34. f. iv.]

Crass. fil. 9-13 $\mu$.

Hab. On trees, summit of Trois Pitons (4500 ft.), Dominica. Nos. 903 and 904. Rather scarce.-On rocks, Roseau Valley (1000-2000 ft.), Dominica. (27-6-92.) No. 24.

Var. TeNue, nov. var. (Pl. XV. figs. 4-S.)

Var. minor, filis tenuioribus, $5 \cdot \bar{\jmath}-\bar{\tau} \mu$ crassis.

Hab. With the typical form, but much more abundant. It was intermixed with Symploca cuspidata, n. sp., Stigonema minuta, Hass., Scytonema ambigua, Kuetz., \&c.

2S. Stigonema panviforme, Bornet et Flah. (Révis. des Nostoc. Hétérocyst. p. 71.) [Scytonema panniformis, Agardh; Sirosiphon panniformis, Kuetz.]

Crass. fil. 23-26 $\mu$.

Hab. With the preceding. Another gathering from the same locality had abundant hyphæ (an incipient lichen). No. 779. Crass. fil. $15-25 \mu$.

29. S. мmutum, Hass. (Hist. of Brit. Freshw. Alg. i. p. 230, t. 67 . ff. 3-4.)

Crass. fil. 19-25 $\mu$.

Hab. On damp wall of dam, Sharp's River, St. Vincent. No. 477. - On trees, summit of Truis Pitons ( $4500 \mathrm{ft}$.$) , Do-$ minica, no. 903 ; and on lime-trees, Shanford Estate, Dominica, no. 901 .

30. S. INforme, Kuetz. (Species Algar. p. 319 ; Tabula phycolog. ii. p. 11, t. 3s. f. iii.)

Crass. fil. $41-52 \mu$.

Hab. On trees, summit of Trois Pitons (4500 ft.), Dominica. Nos. 903 and 904 .

\section{Ord. Oscillariacee.}

31. Stmploca cuspidata, nov. sp. (Pl. XVI. figs. 1-7.)

S. bryophila, late expansa, griseo-lutea; fasciculis erectis, angustis subulatis, aggregatis (passim densis), $\$-15 \mathrm{~mm}$. altis, æruginescentibus; trichomatibus ærugineis, flexuoso-intricatis, in strato strictioribus, apicibus versus fasciculorum, 1-3 in lata vagina inclusis, sæpe interruptis, distincte articulatis; articulis diametro 2-4plo longioribus; vaginis amplis, achrois, pellucidis 
vel interdum stratis parallelis formatis, in ambitu sæpe subrugosis, apice angustioribus et sæpe ramosis.

Diam. trich. (s. vag.) $1 \cdot 9-2 \cdot 3 \mu$; crass. trich. c. vag. $13 \cdot 5-25 \mu$. Hab. On trees, summit of Trois Pitons (4500 ft.), Dominica. Nos. 903 and 904.

Var. LUteofusca, nov. var.

Var. ferruginea, strato denso, 1-2 mm. alto, fasciculis brevioribus, $4-6 \mathrm{~mm}$. (interdum $10 \mathrm{~mm}$.) altis, articulis crassioribus.

Crass. trich. $2 \cdot 5-3.5 \mu$; crass. vag. $15-40 \mu$.

This variety also often has two, three, or more threads in one sheath.

Hab. On rocks, Roseau Valley (1000-2000 ft.), Dominica. (27-6-92.) No. 24.-On bark, windward road to lake (1000$2000 \mathrm{ft.}$ ), Dominica. (25-8-92.) Nos. 513 and 514.-Also on the ground, mostly in old Diablotia holes, Morne Anglais (2300 ft.). (15-7-92.) No. 493. Thicker and coarser sheath.

The specimens preserred in liquid strongly reminded one of Sphagnum cuspidatum; they occurred amongst mosses in penicillate tufts which were subæruginose towards the apices, the sheaths, but not the trichomes, here becoming narrower. Many of the sheaths in the stratum were without trichomes; and in consequence of this, and the broader sheaths at the base, the stratum was paler than the erect fasciculi.

32. Livgara penicillata, Kuetz. (Botan. Zeit. 1847, p. 194.) [Leibleinia penicillata, Kuetz. Species Algar.; Tabula phycolog. i. p. 46, t. 81. f. ii.]

Crass. fil. $3-3 \cdot \check{\mu} \mu$.

Hab. On bed of stream in crater of Grande Soufrière, Dominica. No. 881 .

33. L. subtile, West. (Alg. of the Eng.Lake Distr. in Journ. Roy. Micr. Soc. Dec. 1592, p. 711, pl. x. f. 58.)

Crass. fil. $1 \div \mu$.

Hab. With the preceding.

34. Phormidum Lisgaraceus, fiuetz. (Phycol. gener. p. 194; Tabula phycolog. p. 33, t. 46. f. iii.; Rabh. Fl. Europ. Alg. ii. p. 12t.)

Crass. fil. $3 \cdot 5-4 \mu$.

Mab. On damp wall of dam, Sharp's River, St. Vincent. No. 477.-On old wall, Dominica. (1-8-92.) No.473.

The cells were about as long as broad (sometimes a little longer). 
35. Рhormidium, sp.

Crasss. fil. 1.2-1·כ $\mu$.

Stratum deuse, thin, and dark æruginous.

Hab. On damp wall, Roseau, Dominica. (5-9-92.) No. 546.

\section{Ord. СhroococCace.}

36. Chroococcus mixor, Naeg. (Gattung. einzell.alg. p. 47, t. 1 A. f. 4. Rabh. Fl. Europ. Alg. ii. p. 30.) [Protococcus minor, Kuetz. Species Algar. p. 195; Tabulce phycolog. i. p. 3, t. 3.] (Pl. XVI. fig. 17.)

Diam. cell. $2 \cdot 8-4 \mu$; diam. fam. $11 \cdot 5-30 \mu$.

Hab. On damp wall of dam, Sharp's River, St. Vincent. No. 477.-On trees, summit of Trois Pitons (4500 ft.), Dominica. No. 503.

Forma mivisa. (Pl. XVI. fig. 18.)

Forma cellulis familiisque minoribus quam forma typica.

Diam. cell. s. teg. 1-1:9 $\mu$; diam. fam. 10-23 $\mu$.

Hab. Along with the type from the above-named localities, and also on lime-trees, Shanford Estate, Dominica. No. 901.

37. C. Coll enexs, Naeg. (Rabh. Fl. Europ. Alg. ii. p. 30.)

[Pleurococcus cohærens, Bréb., 1812. Protococcus cohærens, Kruetz.]

Diam. cell. 3.S-6.5 $\mu$ (usque ad $7.5 \mu$ ); diam. fam. 30-173 $\mu$.

Hab. Amongst other algæ on trees, summit of Trois Pitons (1500 ft.), Dominica. No. 903.

This usually occurred in small families, but occasionally in very large ones, and now and then in solitary examples.

38. C. turgides, Naeg. (Gatt. einzell. Aly. p. 46. Rabh. Fl. Europ. Alg. ii. p. 32.) [Protococcus turgidus, Kuetz. Tabulee phycolog.i. p. 5, t. 5. f. i.]

Diam. cell. s. teg. $7 \cdot 5-10 \cdot 5 \mu$, c. teg. 21-23 $\mu$.

Hab. On damp wall of dam, Sharp's River, St. Vincent. No. 477.

A rather small form.

39. C. schizodermaticus, West. (Alg. of the Eng. Lake Distr. in Journ. Roy. Miicr. Soc. Dec. 1892, p. 742, pl. x. ft. 61-63.) (Pl. XVI. fig. 19.)

Diam. cell. s. teg. $11 \cdot 5-13 \mu$; diam. c. teg. $23-28 \mu$.

Hab. With the preceding species, but much more abundant. 
40. Gleocapsa muralis, Kuetz. (Tabula phycolog. i. t. 21. f. i. ; Rabh. Fl. Europ. Alg. ii. p. 36.)

Long. cell. s. teg. $5 \cdot 5-7 \cdot 5 \mu$; lat. cell. s. teg. $2 \cdot 5-3 \mu$; diam. fam. 19-25 $\mu$.

Hab. On damp wall of dam, Sharp's River, St. Vincent. No. 477 .

The cells were longer in relation to their breadth than those figured by Kuetzing (l.c.).

41. G. grass, nov. sp. (Pl. XVI. figs. 11-13.)

$G$. familiis solitariis vel subaggregatis; cellulis magnis, subglobosis vel oblongis, $4-36$ in familiis subglobosis consociatis, membrana cellularum læva vel subtiliter granulata (vide fig. 11), cytioplasmate ærugineo et granuloso; tegumentis subglobosis, ad exteriorem duris sæpe subrugosis, luteo-fuscescentis, lamelis extra cellulas indistinctis, paucis et pallide luteolis.

Diam. céll. s. teg. 9-15 $\mu$ (plerumque $11 \mu$ ); diam. fam. $41-115 \mu$.

Hab. On damp wall of dam, Sharp's River, St. Vincent. No. 477 .

This occurred amongst Nostoc spharicum, Vauch., in no definite stratum; and it is sufficiently distinguished by its large cells and other characters.

42. Gleocapsa, sp.

Crass. cell. s. teg. $2-3 \mu$. Nos. 23 and 24 .

43. Gleocapsa, sp.

Crass. cell. s. teg. $15 \%$. No. 516 .

44. Aphanocapsa elachista, nov. sp. (Pl. XV. figs. 9, 10.)

A. tegumento minutissimo, subgloboso, firmo, gelatinoso non lamelloso, achroo ; cellulis minutissimis, sphæricis, solitariis geminatisve, laxe dispositis ; cytioplasmate homogeneo et aruginoso; tegumentis non aggregatis in thallo distincto.

Diam. cell. $1 \cdot 5-1 \cdot S \mu$ (usque ad $2 \mu$ ); diam. teg. 26-38 $\mu$.

Hab. On trees, summit of Trois Pitons (4500 ft.), Dominica. No. 903.-And in stream, Grande Soufrière, Dominica. No. Sst.

This species seems characteristically distinct by reason of its minute cells in the very small globose colonies, which were scattered amongst other alga.

45. Gleothece linearis, Naeg. (Gattung. einzell. Alg. p. 5\&, t. 1 a. f. 2 ; Rabh. Fl. Europ. Alg. ii. p. 60.) 
Long. cell. sine teg. $5 \cdot 5-6.5 \mu$, c. teg. $13.5 \mu$; lat. cell. sine teg. $1.8 \mu$, c. teg. $9 \cdot 5-10.5 \mu$.

Hab. On damp wall of dam, Sharp's River, St. Vincent. No. 477.

Forma cellulis 5-6plo longius quanı latius. (Pl. XIV. fig. 26.)

Long. cell. s. teg. $11 \cdot 5-13.5 \mu$, c. teg. $21 \mu$; lat. cell. s. teg. $2-2 \cdot 3 \mu$, c. teg. $11 \cdot 5-12 \cdot 5 \mu$.

$H a b$. With the typical form.

46. Gleothece lunatum, nov. sp. (Pl. XVI. fig. 9.)

$G$. cellulis $2-4$ in familiis consociatis, subcrescentiformibus, 2 plo longius quam latius, apicibus acutis; tegumentis universalibus, ovalibus vel ellipticis; cytioplasmate ærugineo et homogeneo.

Lat. cell. $2 \cdot 5-2 \cdot 7 \mu$; apicibus cellularum $4 \cdot 8-5 \cdot 7 \mu$ inter se distantibus ; famil. $325 \times 19 \mu$.

Hab. With Gl. linearis, Naeg., but very scarce.

47. Aphanothece saxicola, Naeg. (L. c. p. 59, t. 1 H. f. 2.) Lat. cell. $1 \cdot 4-1 \cdot 8 \mu$.

Hab. In small masses of $70-120 \mu$ in diameter, amongst mosses on trees, summit of Trois Pitons (4500 ft.), Dominica. Nos. 903 and 904. Rather scarce.

48. A. microscopica, Naeg. (L. c. t. 1 н. f. 1.)

Long. cell. $5 \cdot 5-7 \cdot 5 \mu$; lat. cell. $3 \cdot 8-4 \cdot 1 \mu \mu$; diam. famil. 108$179 \mu$.

Hab. On damp wall of dam, Sharp's River, St. Vineent. No. 477.-Amongst Symploca cuspidata, n. sp., on trees, summit of Trois Pitons (4500 ft.), Dominica. No. 904.

49. Tetrapedia trigora, nov. sp. (Pl. XVI. fig. 8.)

$T$. cellulæ triangulares, lateribus concavis, angulis subrotundatis; a latere visæ ellipticæ; cytioplasmate pallide ærugineo et homogeneo.

Lat. cell. $7 \cdot 2 \mu$; crass. $3 \cdot 6 \mu$.

Hab. On damp wall of dam, Sharp's River, St. Vincent. No. 477 .

Class D I A T O M A C E ж.

50. Epithemia Westermanni, Kuetz. (Pritch.Infus. ed.1861, p. 760 , t. 4. f. 2.)

Hab. In strean, crater of Grande Soufrière, Dominica. Nos. 891 and 908 . 
51. Evnotia Arcus, Ehrenb. (W. Sm. Brit. Diat. ii. t. 33. f. 283.)

Hab. In stream, crater of Grande Soufrière, Dominica. No. 908.

52. E. Gracilts, Rabh. (Fl. Europ. Alg. i. p. 72.) [Himantidium gracile, Ehrnb., W. Sm. Brit. Diat. ii. p. 14, t. 33. f. 285.$]$

Hab. Amongst mosses, on trees, summit of Trois Pitous (4500 ft.), Dominica. No. 903.

53. Odontidium metabile, W. Sm. (Brit. Diat. ii. p. 17, t. 34. f. 290.)

Hab. On damp wall of dam, Sharp's River, St. Vincent. No. 477.

54. Desmogonidm Rabenhorstandm, Grun. (Diat. ins. Banka, p. 6, t. i. f. 1; De Toni, Sylloge Algar. vol. ii. p. 680.)

IIab. Abundant in stream (hot and cold), crater of Grande Soufrière, Dominica. No. 908.

55. Nitzschia parvela, W. Sm. (Brit. Diat. i. p. 41, t. 13. f. 106.)

Hab. On damp wall of dam, Sharp's River, St. Vincent. No. 477 .

56. N. flexelda, Suring. (Alg. Japon. p. 11, t. 1. f. 12.)

Long. $33-44 \mu$; lat. $3 \cdot 3-4 \cdot 8 \mu$.

IIab. In streams, Grande Soufrière, Dominica. Nos. SS1 and 881 .

57. N. Linearis, $W$. Sm. (Brit. Diat. i. p. 39, t. 13. f. 110.)

Hab. On damp wall of dam, Sharp's River, St. Vincent. No.477.-And in streams, Grande Soufrière, Dominica. Nos. Ss1 and 908 .

58. N. minutissima, $W . S m$. (L. c. p. 41, t. 13.f. 107.)

Hab. In stream, Grande Soufricre, Dominica. No. 854 .

59. Naticula cryptocephala, Kuetz. ( $W$. Sm. l. c. p. 53, t. 17, f. 155.)

Hab. On damp wall of dam, Sharp's River, St. Tincent. No. 477 . 
60. Navicula borealis, Kuetz. [Pinnularia borealis, Ehrenb., W. Sm. Brit. Diat. ii. p. 94; Rabh. Fl. Europ. Alg. i. p. 216.]

$H a b$. With the preceding species.

61. N. mesolepta, Ehrenb. [Pinnularia mesolepta, W. Sin. Brit. Diat. i. p. 58, t. 19. f. 182.]

Hab. On bed of stream in crater of Grande Soufrière, Dominica. No. 881.

62. Frustulia rhomboides, De Toni. (Sylloge Algar. vol. ii. p. 227.) [Navicula rhomboides, Ehrenb., W. Sm. Brit. Diat. i. p. 46 , t. 16. f. 129.]

Hab. In stream, crater of Grande Soufrière. No. 908.

Var. saxonic., De Toni. (L.c.) [Frustulia saxonica, Rabh. Navicula crassinervia, Bréb. in W. Sm. Brit. Diat. i. p. 47, t. 31. f. 271.]

Hab. In streams (cold, warm, and hot), crater of Grande Soufrière, Dominica. Nos. 883 and 908.-Also amongst mosses on trees, summit of Trois Pitons (4500 ft.), Dominica. Nos. 903 and 904 .

63. Gomphonema tenellum, Kuetz. (IV. Sm. Brit. Diat. i. p. 80, t. 29. f. 243.)

Hab. On damp wall of dam, Sbarp's River, St. Vincent. No. 477 .

\section{EXPLANATION OF THE PLATES.}

\section{Plate XIII.}

Figs. 1-4. Zygnema (§ Zygogonium) pachydermum, n. sp. Conjugated specimens, $520 / 1$.

5-8. Ditto. Four zygospores, 520 1.

9, 10. Ditto. Two specimens, with azygospores, $520 / 1$.

11-15. Ditto, sterile filaments; fig. 11, 520/1; figs. 12-15, filaments, showing short branches, 120/1.

Fig. 16. Ditto, showing conjugation between three filaments, 120/1.

Fig. 17. Cosmarium obliquum, Nordst., f. minor, Nordst., 520,1.

\section{Plate XIV.}

Figs. 1-6. Zygnema pachydermum, n. sp., var. confervoides, n. var. Figs. 1 \&2, filaments without cell-contents; fig. 3 , filament with contents delineated ; fig. 4 , attempt at conjugation ?; fig. 5, cells showing longitudinal division. Figs, $1-5,520 / 1$; fig. 6, 830/1.

7-11. Microchate tenuissima, n. sp. 520/1.

12-15. Scytonema javanicum, Bornet. 520/1. 
Plate XIV. (continued).

Fig. 16. Cerasterias staurastroides, n. sp. 520/1.

Figs. 17-24. Rhizoclonium Berggrenianum, Hauck, var. dominicense, n. var. $520 / 1$.

Fig. 25. Cosmarium pseudopyramidatum, Lund, * stenonotum, Nordst., f. minor, Racib. 520/1.

Fig. 26. Gloeothece linearis, Naeg., forma. 520/1.

\section{Plate XV.}

Figs. 1-3. Hapalosiphon arboreus, n. sp. 520/1.

4-8. Stigonema hormoides, Bornet et Flab., var."tenue, n. var. 520/1. $h$, heterocysts.

9-10. Aphanocapsa elachista, n. sp. 520/1.

11-15. Scytonema ambiguum, Kuetz. 520/1.

16-28. Hapalosiphon intricatus, n. sp. 520/1.

\section{Plate XTI.}

Figs. 1-7. Symploca cuspidata, n. sp. Fig. 1, natural size; fig. 2, a rery small portion of oue of the erect fasciculi, $120 / 1$; fig. 3 , a specimen showing three trichomes in one sheath, $120 / 1$; figs. $4 \& 5$, examples with two trichomes in one sheath, $520 / 1$; figs. $6 \& 7$, the apices of two filaments, showing in fig. 6 a broad sheath at the apex, and in fig. 7 a narrow one, 520,1 .

Fig. $\quad$ 8. Tetrapedia trigona, n. sp. $830 / 1$.

9. Gloothece lunatum, n. sp. 520/1.

10. Eudorina stagnale, Wolle, var. 520/1.

Figs. 11-13. Gloocapsa gigas, n. sp. 520,1. Fig. 11, an example Laving the cells with finely granulate walls; fig. 12 , one where the lamellse round the cells are not visible.

14-16. Scytonema amplum, n. sp. 520/1.

Fig. 17. Chroococcus minor, Naeg. 520/1.

18. " " $" \quad$ f. minima. $520 / 1$.

19. " schizodermaticus, West. 520/1. 


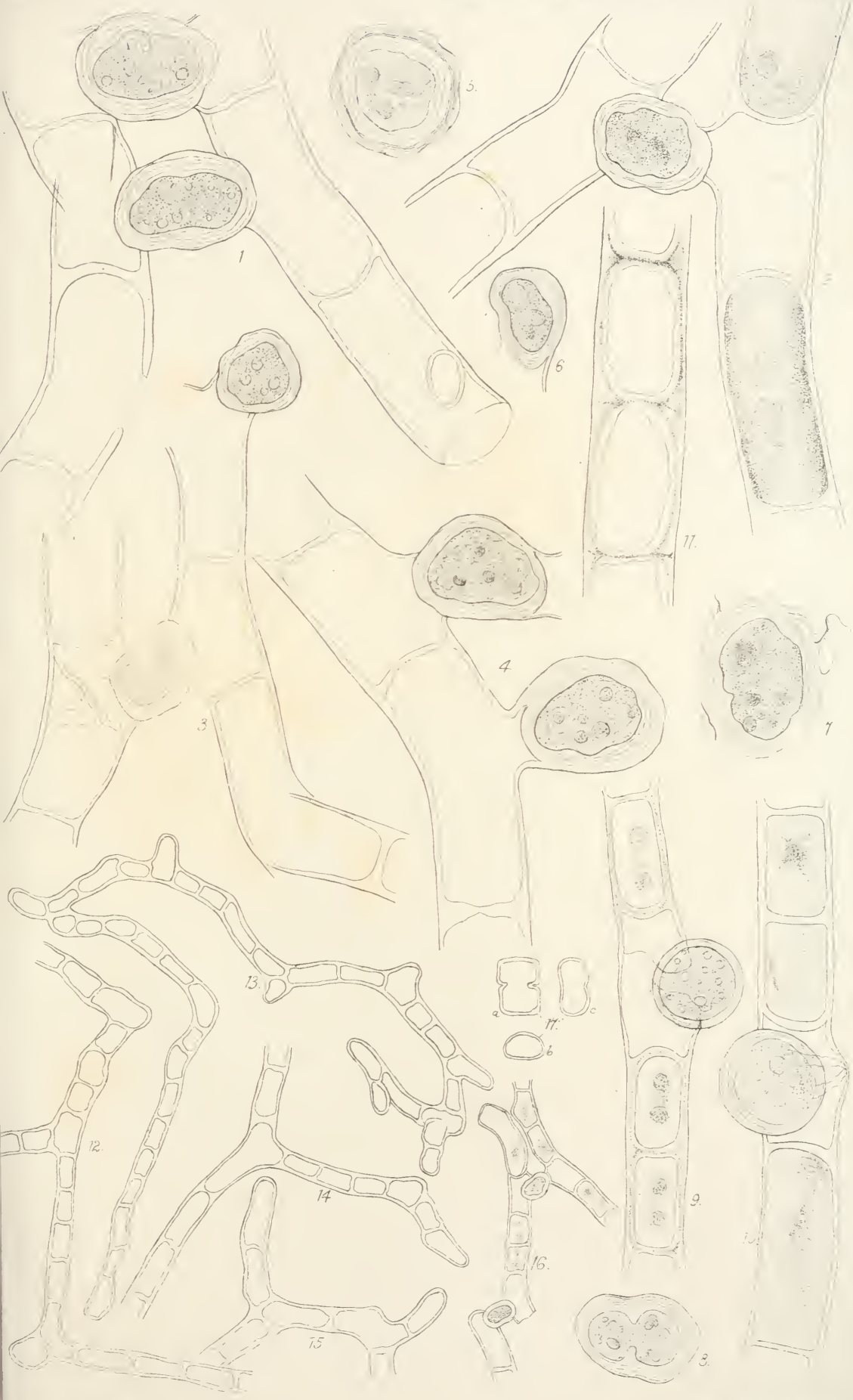

FAFSIWATER ATGA OF WEST TNDIES 



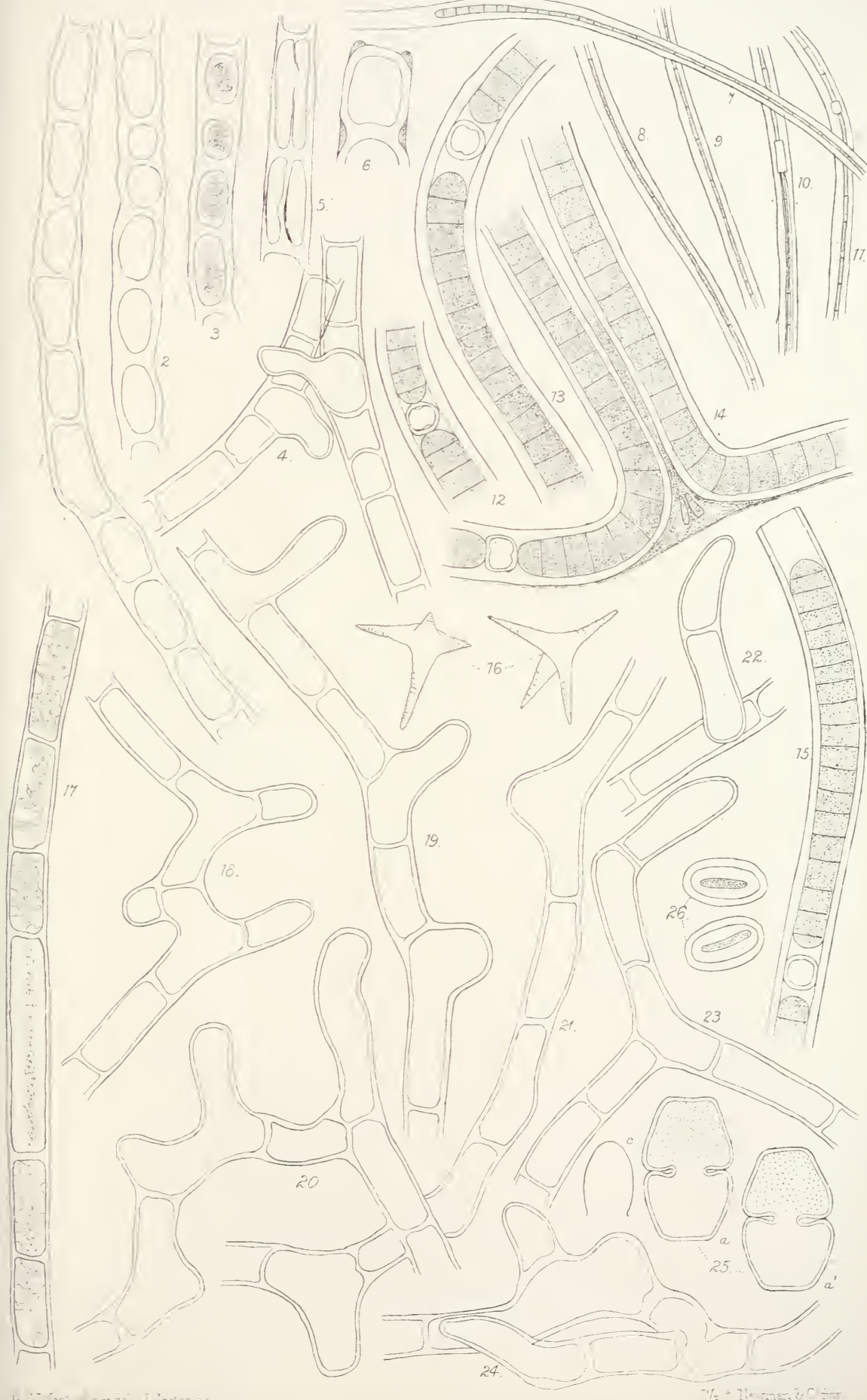



1)

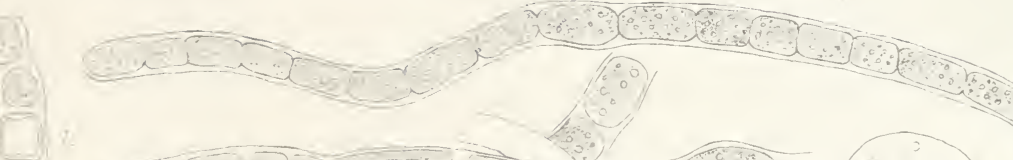

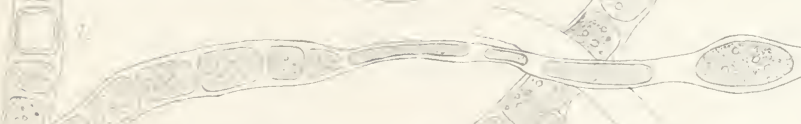
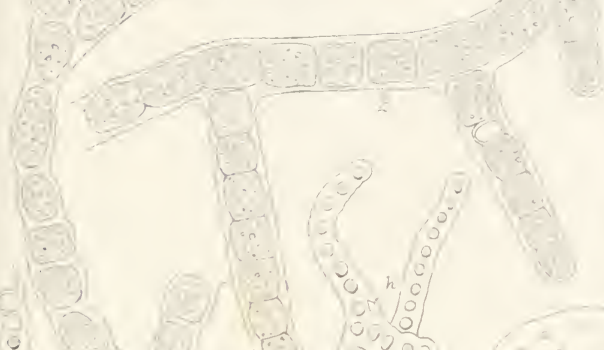

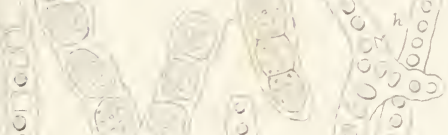



0
0
0
0
0
0

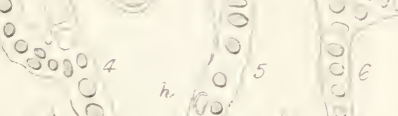

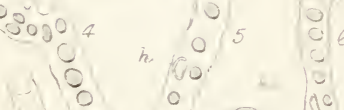

$\left(\begin{array}{lll}0 & 0 \\ 0 & 0 & 0\end{array} \Rightarrow\left(\begin{array}{l}0 \\ 0 \\ 0 \\ 0 \\ 0\end{array}\right.\right.$

(

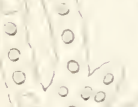

$0_{0}^{0,-15}$

10
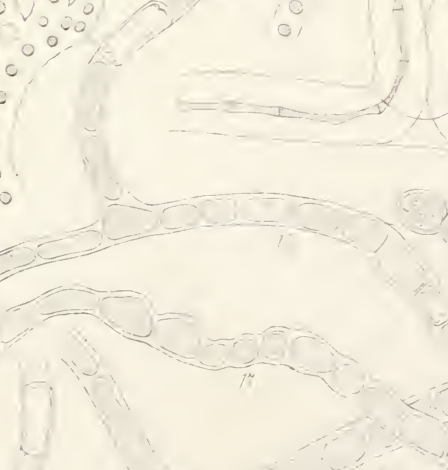

$\therefore=\frac{1}{3 x}$ 


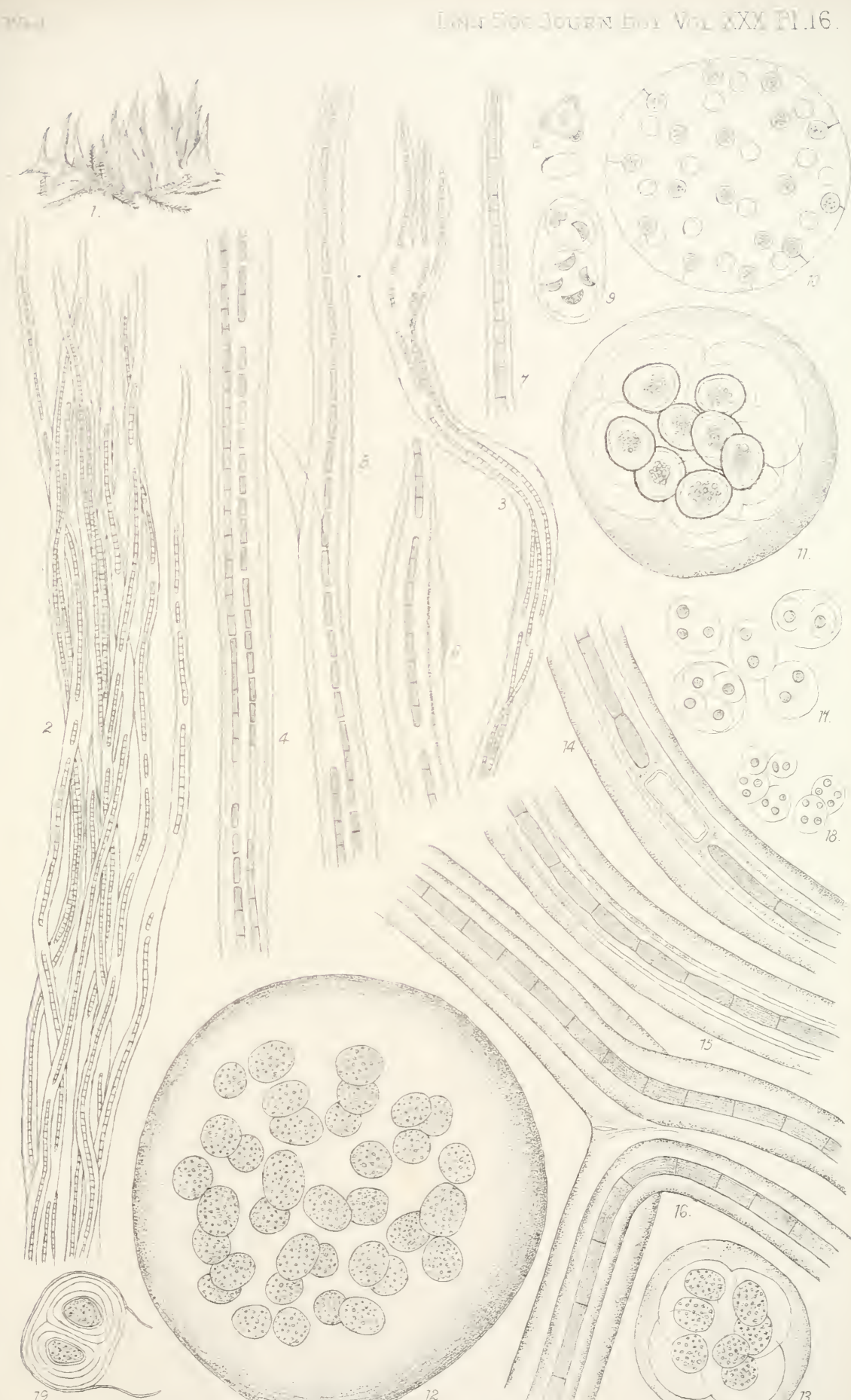



QK572. We w York Botanical Garden Library West. William/On some freshwater algae f gen

35185001159217 
